\title{
COST-BENEFIT ANALYSIS OF ADVANCED, SANITARY SEWAGE TREATMENT AT ROCKY FLATS
}

John A. Zillich

John D. Hurley

Environmental Sciences

WASTE MANAGEMENT GROUP

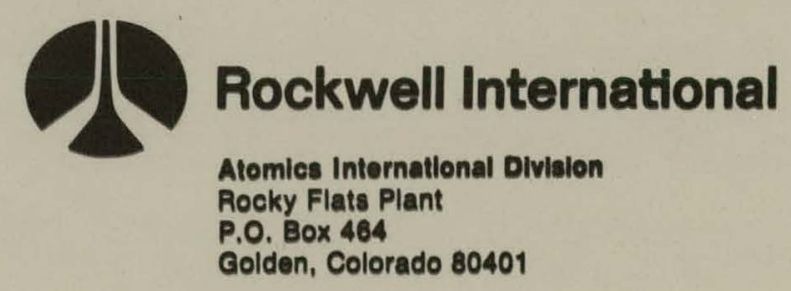

U.S. ENERGY RESEARCH AND DEVELOPMENT ADMINISTRATION CONTRACT EY-76-C-04-3533 


\section{DISCLAIMER}

This report was prepared as an account of work sponsored by an agency of the United States Government. Neither the United States Government nor any agency Thereof, nor any of their employees, makes any warranty, express or implied, or assumes any legal liability or responsibility for the accuracy, completeness, or usefulness of any information, apparatus, product, or process disclosed, or represents that its use would not infringe privately owned rights. Reference herein to any specific commercial product, process, or service by trade name, trademark, manufacturer, or otherwise does not necessarily constitute or imply its endorsement, recommendation, or favoring by the United States Government or any agency thereof. The views and opinions of authors expressed herein do not necessarily state or reflect those of the United States Government or any agency thereof. 


\section{DISCLAIMER}

Portions of this document may be illegible in electronic image products. Images are produced from the best available original document. 


\section{LEGAL NOTICE}

This report was prepared as an account of work sponsored by the United States Government. Neither the United States nor the Energy Research and Development Administration, nor any of their employees, nor any of their contractors, subcontractors, or their employees, makes any warranty, expressed or implied, or assumes any legal liability or responsibility for the accuracy, completeness or usefulness of any information, apparatus, product or process disclosed, or represents that its use would not infringe privately owned rights.

Printed in the United States of America

Available from the

National Technical Information Service

U. S. Department of Commerce

Springfield, Virginia 22161

Price: Printed Copy $\$ 4.50$ Microfiche $\$ 3.00$

Price Is Subject to Change Without Notice 
TID-4500-R65

\section{COST-BENEFIT ANALYSIS OF ADVANCED, SANITARY SEWAGE TREATMENT AT ROCKY FLATS}

John A. Zillich

John D. Hurley

Environmental Sciences

WASTE MANAGEMENT GROUP

\section{SUBJECT DESCRIPTORS}

Tertiary Treatment

Wastewater

Sanitary Sewage

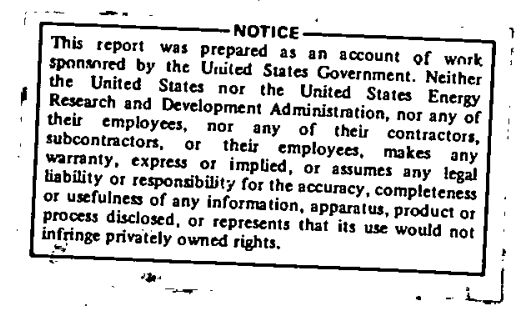

ROCKWELL INTERNATIONAL ATOMICS INTERNATIONAL DIVISION ROCKY FLATS PLANT

P. 0. BOX 484

GOLDEN, COLORADO 80401

Propared undor Contraet EY-70-C-04s833

for the

Albuquerque Operations Offles

U. 8. Enorgy Research and Dovelopment Administration 


\section{THIS PAGE \\ WAS INTENTIONALLY \\ LEFT BLANK}




\section{O N T E N T S}

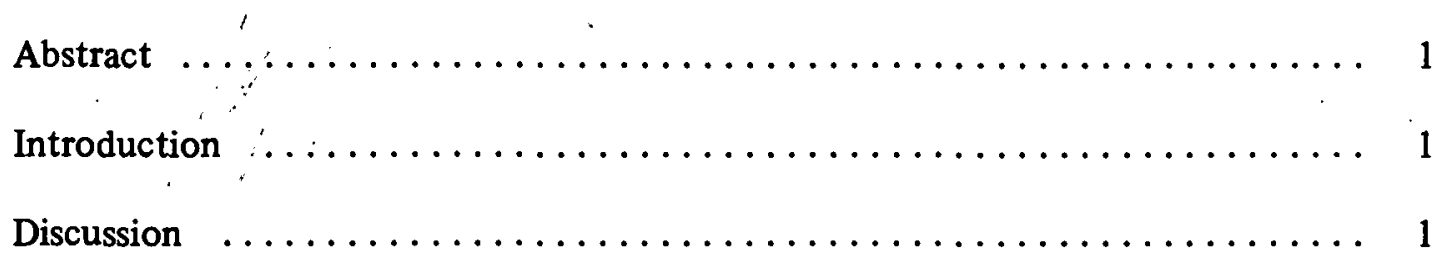

Sanitary Sewage Treatment Plant Design and Operation $\ldots \ldots \ldots \ldots \ldots \ldots$

Sampling and Analytical Procedures $\ldots \ldots \ldots \ldots \ldots \ldots \ldots$

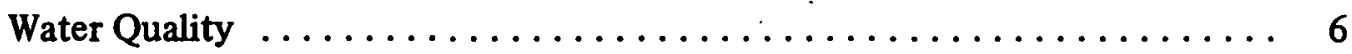

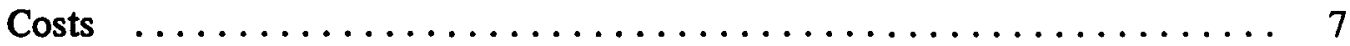

Cost-Benefit Analysis $\ldots \ldots \ldots \ldots \ldots \ldots \ldots \ldots \ldots \ldots \ldots \ldots \ldots$

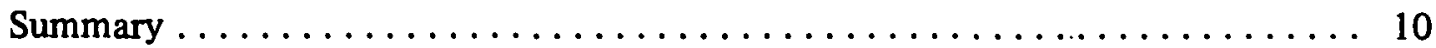

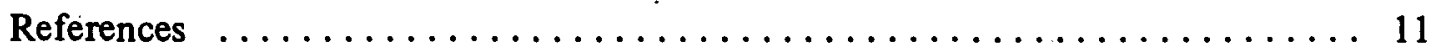




\section{THIS PAGE \\ WAS INTENTIONALLY \\ LEFT BLANK}


RFP-2423

\title{
COST-BENEFIT ANALYSIS OF ADVANCED, SANITARY SEWAGE TREATMENT AT ROCKY FLATS
}

\author{
John A. Zillich and John D. Hurley
}

\begin{abstract}
A small, secondary treatment plant for processing sanitary wastes was upgraded by the addition of tertiary treatment (chemical treatment and final clarification) and mixed-media filtration. Operational data showed that the tertiary treatment significantly reduced pollutants. Filtration further reduced suspended solids significantly and removed some additional phosphorus; however, no additional reduction in total oxygen demand or in nitrogen was noted. Detailed analyses of costs for construction and routine operations showed the cost of tertiary treatment was small compared to costs associated with mixed-media filtration.
\end{abstract}

\section{INTRODUCTION}

The sanitary sewage treatment facility at Rocky Flats receives sanitary wastes from about 3,000 employees in addition to cooling tower blowdowns and other industrial wastes. In late 1974, the existing secondary-treatment plant was upgraded, and tertiary treatment facilities consisting of chemical treatment, final clarification, and mixed media filtration were installed. At that time, approximately 175,000 gallons of effluent were being discharged daily to holding ponds. Those ponds permit settling and sampling of the effluents and contribute to the municipal water supply of Broomfield, Colorado. Thus, the quality of these effluents is of the utmost importance. This report describes the step-by-step reduction of waste as that waste progresses through the sanitary sewage treatment plant. Also included is an analysis of treatment costs.

\section{UISCUSSION}

\section{Sanitary Sewage Treatment Plant Design and Operation}

Figure 1 is a schematic diagram of the plant showing the volumes of the various components and the flow during a 14-day study period (March 31-April 13, 1975). Incoming waste was held in two 40,000gallon basins to equalize flow. From there, the waste flow was divided equally at the splitter box and sent to the primary clarifiers. Sludge from the primary clarifiers was pumped once every eight hours. The aerators were "Chicago Pump®" combination aerator-clarifier units (Figure 2), with 10-hp blowers added to improve aeration and solids suspension. This improvement was achieved by diffusers at 5-foot intervals around the perimeter of the aerator portion. Aeration and solids suspension was accomplished by running the blowers 5 minutes on, then 5 minutes off. The only time the original (Chicago Pump) aerator pumps were used was during sludge removal. Activated sludge concentrations were measured by the Environmental Protection Agency's (EPA) operational control procedures, using settleometers and centrifuge tests. ${ }^{1,2}$ The concentrations of activated sludge started out low in Number 2 and 3 aerators and increased throughout the study. Optimal aeration tank concentrations were 3.0 to 3.5 units (see Table 1). Flow data also is presented in Table 1. Wastewater temperatures varied between 12 and $14{ }^{\circ} \mathrm{C}$ during this study.

The three days prior to the start of this study period was the Good Friday, three-day weekend when little waste entered the sewage treatment plant. This resulted in a subsequent reduction in aerator solids. Aerator effluent entered a chemical mixing pit where alum was added continuously to give a 40$\mathrm{mg} / \mathrm{l}$ concentration of alum. Purifloc $\circledast$ A-23 was added continuously to the effluent immediately downstream of the chemical mixing pit to give a $0.5 \mathrm{mg} / \mathrm{l}$ concentration. Sludge was removed from the final clarifier once during every 8 -hour shift, and water from the final clarifier flowed, by gravity, to the catch basin where it was pumped to three mixed media filters (Figure 3 ). The filtered effluent then entered a clear well and subsequently flowed through two chlorine contact basins for disinfection. 
FIGURE 1. Flow of Sanitary Sewage During Treatment

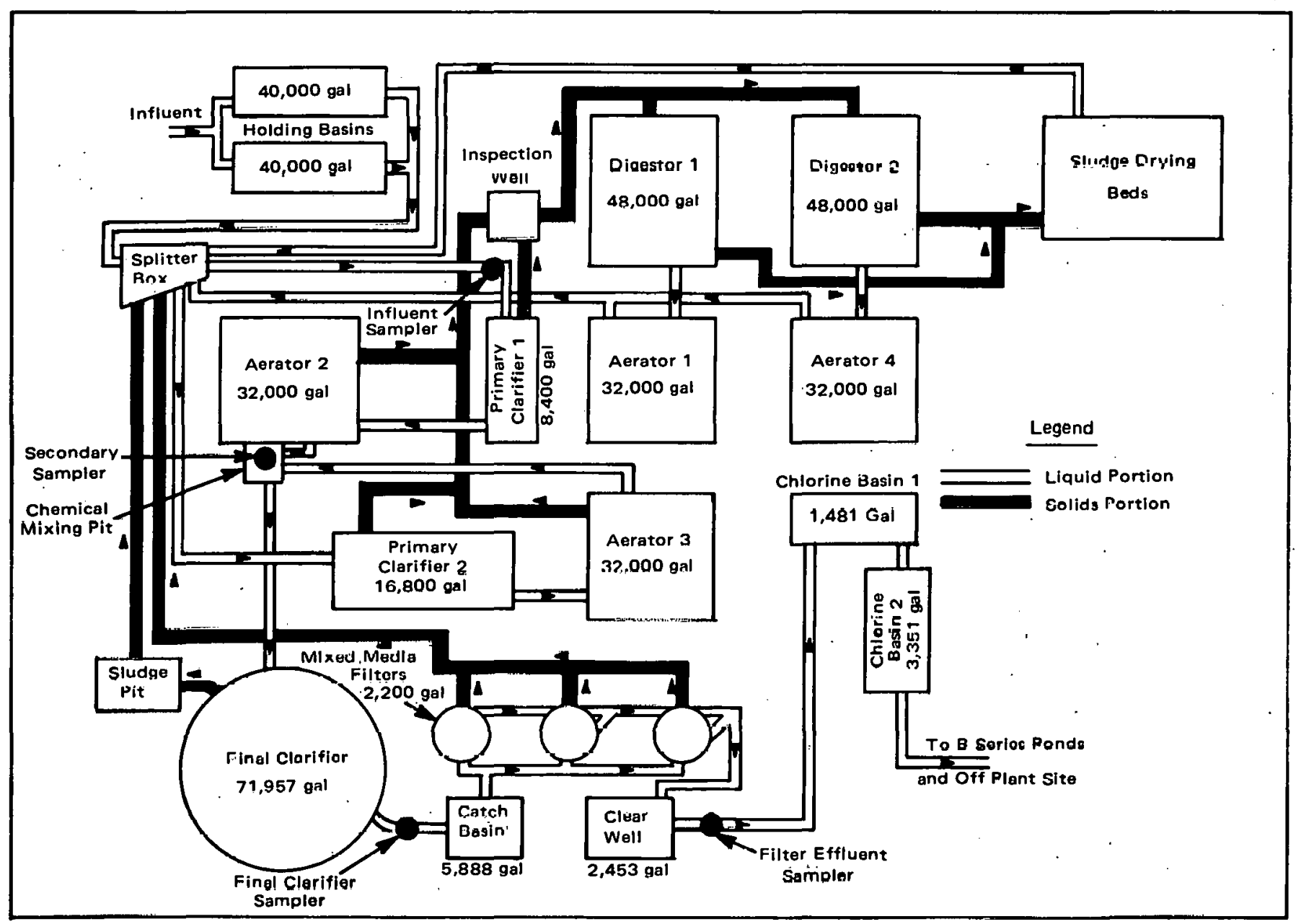


FIGURE 2. A Modified "Chicago Pump" Aerator-Clarifier

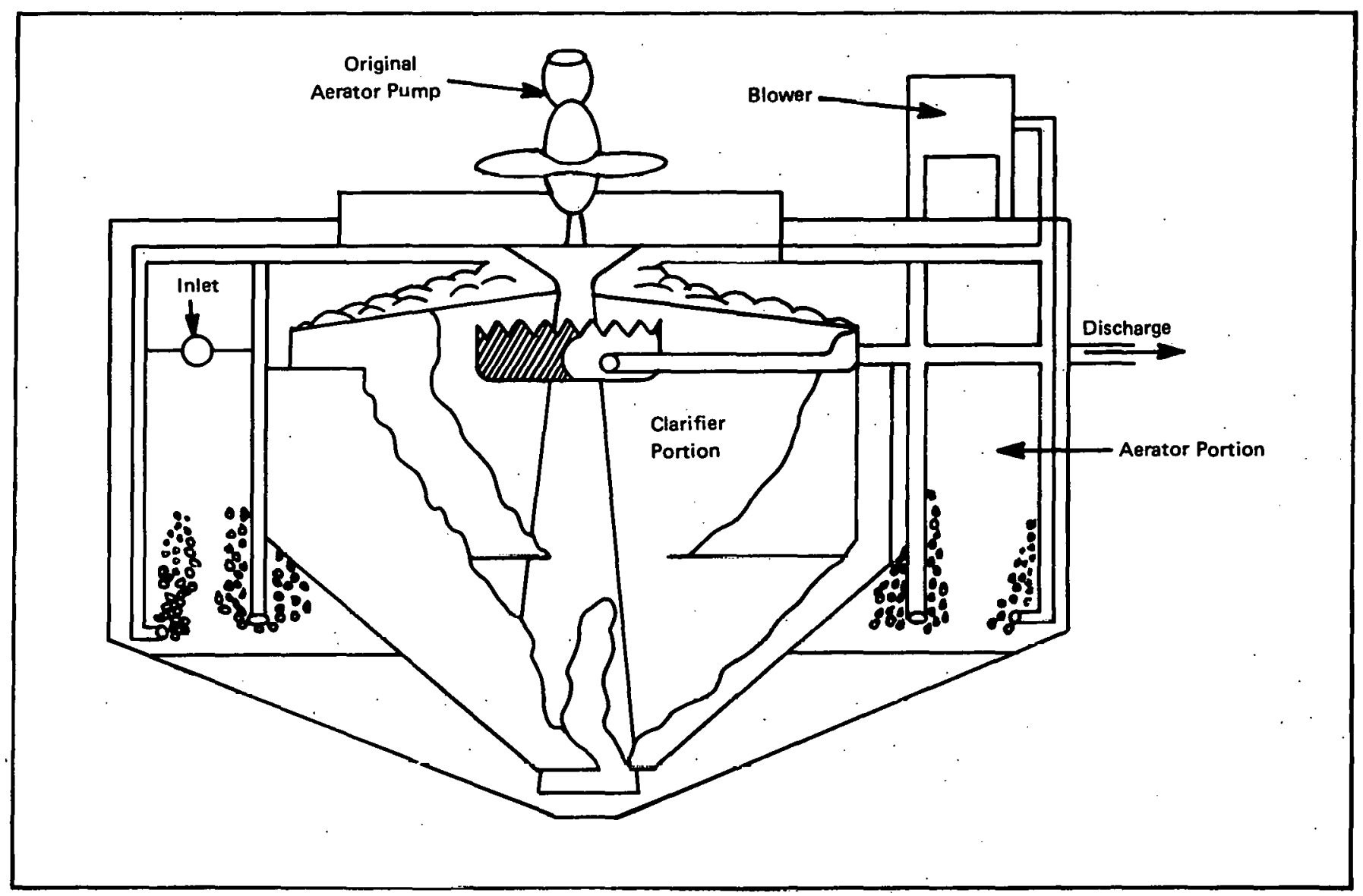


TABLE I. Aerator Sludge Characteristics and Flow Data

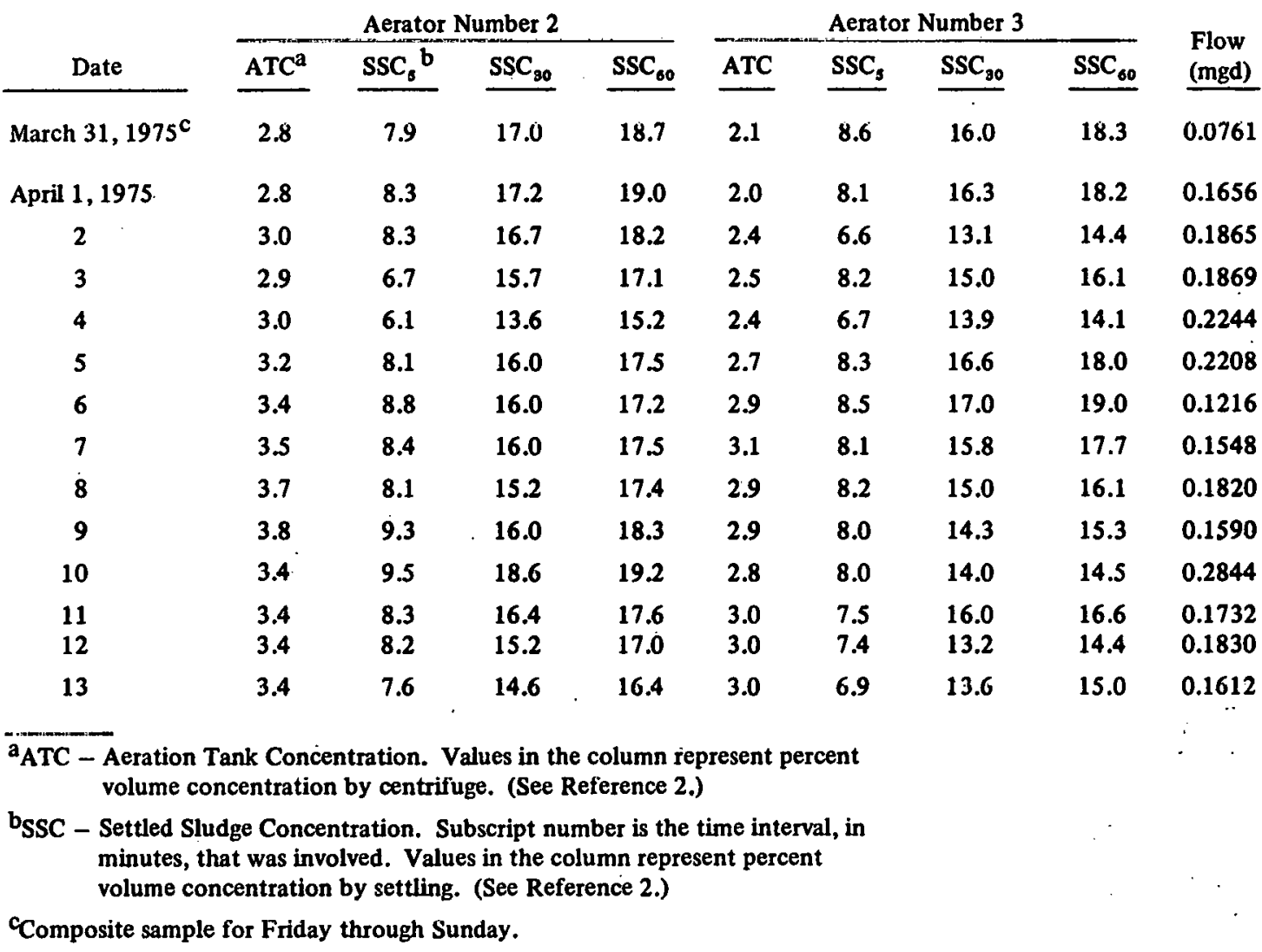

All digestor supernatant was pumped to either Number 1 or Number 4 aerators, which were converted for this study to aerobic digestors. There the supernatant was mixed with primary sludge, and the mixture was aerated to convert ammonia and organic nitrogen to nitrates. The aerator was turned off, and methanol was added. The mixture next went to an anoxic condition, and the nitrates presumably were reduced to nitrogen gas and carbon dioxide. The aerator then was turned on again to return the mixture to an aerobic condition. On the following weekend, the mixture was pumped back into the-splitter box, which also received other influent. This procedure not only eliminated nitrogen, it also provided a much needed food source to the activated sludge during weekends when the amount of incoming waste otherwise would probably not have been sufficient to keep the bacteria healthy.

From March 24 to March 30, 1975, all primary sludge was pumped to Number 4 aerator in antici- pation of the upcoming three-day weekend. This sludge was aerated until March 28 when the aerator was turned off, and five gallons of methanol was added. But because of extremely cold weather, this mixture could not be pumped to the splitter box during the weekend of March 29 and 30, 1975. The mixture remained undisturbed in the aerator until April 5 when the material was returned to an aerobic condition and subsequently was pumped to the splitter box.

From March 31 to April 5, 1975, all primary sludge was pumped to Digestor Number 1. From April 5 to April 12,1975, two-thirds of the primary sludge was pumped to Aerator Number 1 while one-third went to Digestor Number one. This sludge was aerated beginning Aprll 10. On April 11, 5 gallons of methanol was added and the solution was allowed to become anoxic. On April 12, this solution was pumped to the splitter box. This pumping ceased April 13, 1975. 
FIGURE 3. Composition of Mixed Media Filter

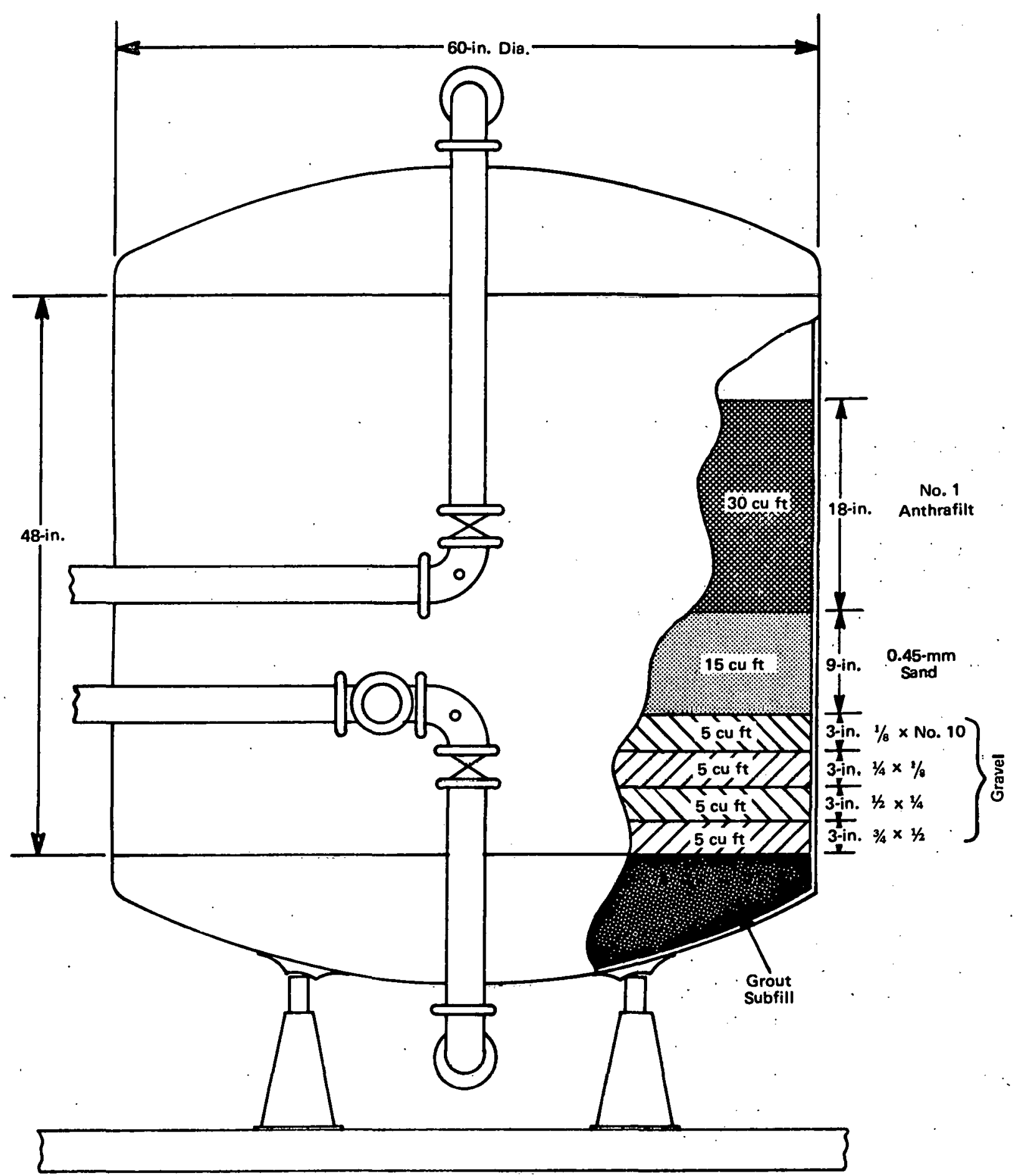




\section{Sampling and Analytical Procedures}

Samples were collected at four sites. The influent was sampled just upstream of the number 1 primary clarifier. Aerator (secondary) effluent was sampled at the chemical mixing pit, and effluent from the final clarifier was sampled in the catch basin. These three points were sampled automatically at least twice every 15 minutes. The filtered effluent was collected manually every hour from the clear well.

Daily samples were collected over a 24-hour period and sent to the laboratories for analysis. Weekend samples consisted of Friday, Saturday, and Sunday waters. They were collected on a daily basis and frozen. On the following Monday, the three daily samples were thawed, composited, and analyzed as one sample. Each sample was analyzed for the following eight parameters: (1) suspended solids concentrations, as determined by the nonfilterable method; (2) total phosphorus by the single reagent method; (3) total organic carbon by the total and dissolved method; (4) total nitrogen by the Kjeldahl method; (5) ammonia by distillation; (6) organic nitrogen by subtracting ammonia nitrogen from total nitrogen; 3 and (7-8) nitrate phenoldisulfonic and chemical oxygen demand, as determined by the nitrate phenoldisulfonic acid and dichromate reflux methods. 4

\section{Water Quality}

The daily removal of suspended solids for a twoweek period is shown in Table 2. Reasons for the large amount of solids remaining in the secondary effluent for March 31 and April 2 are not known. No upsets were noted during this period; however, this is not to say that these numbers are not real numbers. Since the addition of tertiary treatment facilities, the aerator-clarifier effluent has flowed underground to the chemical mixing pit and has been much less conspicuous than before; consequently, an upset could have occurred without being noticed. Average suspended solids concentrations and percent removals showed the greatest amount of solids were removed in the initial treatment steps (Table 3).

The average influent, secondary effluent, clarified effluent, and filtered effluent contained total
Table 2. Daily Suspended Solids Removal

\begin{tabular}{|c|c|c|c|c|c|}
\hline & & & & uent $(\mathrm{mg} / 1$ & \\
\hline & Dale & $(\mathrm{mg} / \mathrm{l})$ & Secondary & Clarified & Filtered \\
\hline March & $31,1975^{*}$ & 50 & 106 & 16 & 2 \\
\hline April & 1,1975 & 133 & 17 & 13 & 5 \\
\hline & 2 & 335 & 284 & 16 & 8 \\
\hline & 3 & 281 & 34 & 5 & 1 \\
\hline & 4 & 88 & 11 & 10 & 3 \\
\hline & 5 & 84 & 22 & 8 & 4 \\
\hline & 6 & 84 & 22 & 8 & 4 \\
\hline & 7 & 83 & 31 & 14 & 6 \\
\hline & 8 & 247 & 8 & 3 & 3 \\
\hline & 9 & 115 & 53 & 17 & 3 \\
\hline 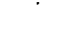 & 10 & 114 & 35 & 10 & $<2$ \\
\hline & 11 & 146 & 3 & 5 & 2 \\
\hline & 12 & 146 & 3 & 5 & 2 \\
\hline
\end{tabular}

*Composite of Friday, Saturday, and Sunday samples.

TABLE 3. Average Suspended Solids Concentrations in Rocky Flats Wastes

\begin{tabular}{lccc}
$\begin{array}{l}\text { Influent } \\
(\mathrm{mg} / \mathrm{l})\end{array}$ & $\frac{3}{3}$ Effluent $(\mathrm{mg} / \mathrm{l})$ \\
\cline { 2 - 4 } 146.6 & $\frac{\text { Secondary }}{48.4}$ & Clarified & Filtered \\
\hline
\end{tabular}

phosphorus concentrations of $3.4,2.7,1.7$, and $1.4 \mathrm{mg} / 1$ respectively. This poor removal is believed to be the result of inadequate mixing of alum and Purifloc feed solutions with the waste.

During the study period, approximately 60 percent of the effluent nitrogen was in the nitrate form (Table 4). Past experience has shown that the aeration basin greatly increases nitrification. Nitrification was not done, however, because at the time of the study, the Environmental Protection Agency discharge permit for Rocky Flats required a $10-\mathrm{mg} / 1$ maximum average discharge of nitrate nitrogen. ${ }^{5}$ 
TABLE 4. Average Ammonia, Organic, Nitrate, and Total Nitrogen Concentrations in Rocky Flats Wastewater

\begin{tabular}{lccccc} 
& $\begin{array}{c}\text { Influent } \\
(\mathrm{mg} / \mathrm{l})\end{array}$ & & \multicolumn{3}{c}{ Secfluent (mg/l) } \\
\cline { 2 - 3 } \cline { 5 - 6 } \cline { 5 - 6 } Ammonia Nitrogen & 13.2 & & 4.5 & 4.4 & 4.6 \\
Organic Nitrogen & 7.1 & & 1.7 & 0.7 & 0.6 \\
Nitrate Nitrogen & 1.2 & & 6.7 & 8.4 & 9.6 \\
TOTAL NITROGEN & 21.5 & & 12.9 & 13.5 & 14.8 \\
\hline
\end{tabular}

There are some unusual relationships in the relative amounts of nitrogen at various sampling points within the system. Theoretically one would expect a decrease in ammonia and organic nitrogen during progressive stages in the treatment plant. The data indicate, however, that the ammonia nitrogen stayed about the same once it reached the secondary effluent. There was a distinct drop in organic nitrogen from the secondary to the final clarified effluent, but there.was little or no reduction in the organic nitrogen between the clarified and filtered effluent. Nitrate nitrogen concentrations progressively increased, but they did not correspond to the reductions in ammonia and organic nitrogen concentrations. The unaccounted-for nitrogen may be in nitrite nitrogen, which was not measured.

Chemical oxygen demand (COD) frequently is thought of as measuring the carbonaceous oxygen demand, but it also measures some inorganic oxygen demand. It does not measure the oxygen demand attributed to nitrogenous compounds. Chemical . treatment and clarification reduced the chemical oxygen demand of the secondary effluent from 52 to $25 \mathrm{mg} / 1$ (Table 5); however, there was no further reduction in chemical oxygen demand when the clarified effluent was filtered.

Total oxygen demand (TOD) measurements were not made on these wastewaters, but a calculated total oxygen demand was determined by adding the chemical oxygen demand and the nitrogenous oxygen demand (NOD). The nitrogenous oxygen demand was attributed to unoxidized ammonia and organic nitrogen. Under aerobic conditions, all ammonia and organic nitrogen is oxidized to nitrates.
TABLE 5. Chemical Oxygen Demand, Nitrogenous Oxygen Demand, and Calculated Total Oxygen Demand of Rocky. Flats Wastewaters

\begin{tabular}{|c|c|c|c|c|}
\hline & \multirow{2}{*}{$\begin{array}{l}\text { Influent } \\
(\mathrm{mg} / \mathrm{l})\end{array}$} & \multicolumn{3}{|c|}{ Effluents $(\mathrm{mg} / \mathrm{l})$} \\
\hline & & Secondary & Clarified & Filtered \\
\hline $\begin{array}{l}\text { Chemical Oxygen } \\
\text { Demand }\end{array}$ & 227 & 52 & 25 & 27 \\
\hline $\begin{array}{l}\text { Nitrogenous Oxygen } \\
\text { Demand }\end{array}$ & 69 & $\cdot 33$ & 24 & 22 \\
\hline $\begin{array}{l}\text { Calculated Total } \\
\text { Oxygen Demand }\end{array}$ & 296 & 85 & 49 & 49 \\
\hline
\end{tabular}

For this to occur, each milligram of ammonia and organic nitrogen requires about $4.7 \mathrm{mg}$ of oxygen. The nitrogenous oxygen demand therefore was determined by multiplying the milligrams of ammonia and organic nitrogen by 4.7 .

Reductions in nitrogenous oxygen demand and total oxygen demand followed a pattern similar to that of chemical oxygen demand reduction, i.e., a marked reduction from the secondary effluent to the clarified effluent but virtually no reduction from the clarified effluent to the filtered effluent (Table 5).

It is most important to note that no additional oxygen demand was removed by filtration. Apparently, suspended solids removed by the filters were virtually inert in respect to having an oxygen demand.

\section{Costs}

\section{Construction Costs}

In determining relative construction costs, all equipment common to secondary and advanced waste-treatment facilities has been included in construction costs of the secondary treatment facility. The Rocky Flats sanitary sewage treatment plant originally was built as a secondary treatment plant. Tertiary treatment facilities were added later. It is anticipated that in most cases where tertiary treatment facilities are built, they will be 
TABLE 6. Construction Costs of Facilities for Producing Secondary, Tertiary Clarified, and Filtered Effluent at the Rocky Flats Sewage Treatment Plant

\begin{tabular}{|c|c|c|}
\hline & $\begin{array}{c}\text { Cost } \\
(\$ \text { million })\end{array}$ & $\begin{array}{c}\text { Cost Increase Above } \\
\text { Sccondary Facilities } \\
(\%)\end{array}$ \\
\hline $\begin{array}{l}\text { Secondary Effluent } \\
\text { Facilities }\end{array}$ & 1.0 & - \\
\hline $\begin{array}{l}\text { Chemical Treatment and } \\
\text { Clarification Facilitips }\end{array}$ & 109 & 9.0 \\
\hline $\begin{array}{l}\text { Mixed Media Filtration } \\
\text { Facilities }\end{array}$ & 1.27 & 27.0 \\
\hline
\end{tabular}

added to an existing secondary-treatment plant. For example, the cost of the building to house treatment-plant personnel and all equipment associated with the digestion and drying of sludge is considered in the construction cost associated with secondary treatment. In this case, the treatment plant was not operating at peak capacity, and this equipment was adequate to handle the additional solids removed by tertiary treatment. The secondary treatment plant was built in several expansions, but today's replacement cost is estimated to be about $\$ 1$ million.

Cost of the chemical mixing pit and final clarifier was $\$ 95,000$. Incremental construction cost of producing a chemically treated clarified effluent (hereatter referred to as a tertiary clarified effluent) was an additional 8 percent. The incremental cost of the mixed media filters and associated pumping equipment was $\$ 175,000$. The cost for installing current tertiary treatment facilities therefore was $\$ 95,000$ plus $\$ 175,000$ for a total of $\$ 270,000$. These increased construction costs for producing a filtered effluent over the secondary effluent amounted to an additional 27 percent. The costs are summarized in Table 6.

\section{Operating Costs}

Operating costs were estimated on the basis of the number of man-hours involved in the operation (including man-hours in the analytical laboratory), energy requirements, and chemical costs. Maintenance expenses were not included in total operating costs.
TABLE 7. Man-Hour Costs Involved in Producing A Secondary, Tertiary Clarified, and Filtered Effluent

\begin{tabular}{|c|c|c|c|}
\hline Effluent & Man-hours/day & $\begin{array}{c}\text { Dollars/day } \\
\text { at } \$ 6.47 / \text { hour }\end{array}$ & $\begin{array}{l}\text { Additional Cost } \\
\text { Above Secondary } \\
(\%)\end{array}$ \\
\hline Secondary & 26.6 & 172 & - \\
\hline Tertiary Clarified & 30.1 & 195 & 13.4 \\
\hline Filtered & 35.5 & 230 & 33.7 \\
\hline
\end{tabular}

TABLE 8. Energy Costs Associated with the Production of Secondary, Tertiary Clarified, and Filtered Effluent

\begin{tabular}{|c|c|c|c|c|}
\hline \multirow[b]{2}{*}{ Effluent } & \multirow[b]{2}{*}{$\begin{array}{l}\text { Electrical } \\
(\$ / \text { day })+\end{array}$} & \multirow[b]{2}{*}{$\begin{array}{c}\text { Digestor Gas } \\
\text { (\$/day) }\end{array}$} & \multicolumn{2}{|c|}{ Total Energy Cost } \\
\hline & & & $=(\$ /$ day $)$ & $\begin{array}{l}\text { Cost Above } \\
\text { Secondary } \\
(\%)\end{array}$ \\
\hline Secondary & 3.46 & 2.53 & 5.99 & - \\
\hline Tertiary Clarified & 3.59 & 3.19 & 6.78 & 13.0 \\
\hline Filtered & 5.03 & 3.29 & 8.32 & 39.0 \\
\hline
\end{tabular}

Since the start-up of tertiary treatment, a considerable amount of the work done by maintenance personnel was associated with improving secondary treatment, and figures for routine maintenance items could not be separated.

Twenty-six man-hours woro required ench day for direct operation of secondary treatment facility. An additional 4.5 hours were required to add the chemicals and run the final clarifier, and 4.5 hours morc were required to operate the mixed-media filtration equipment (Table 7). Included in these figures are 3.5 man-hours per day for mandatory measurements associated with the Environmental Protcction Agonoy disoharge permit. Suspended solids, phosphorous, fluoride, $\mathrm{pH}$, nitrate, color, and grease analyses were required and performed daily while biochemical oxygen demand and dissolved oxygen tests were required three timcs a week. A chemical oxygen demand analysis also was performed daily, but that was not required by the Environmental Protection Agency.

Energy consumption was determined by direct measurement of all electric motors (Table 8). 
TABLE 9. Summary of Operational Costs For Secondary Treatment, and of Incremental Costs For Tertiary Clarification and Mixed-Media Filtration

\begin{tabular}{|c|c|c|c|c|c|}
\hline & $\begin{array}{l}\text { Labor } \\
\text { (\$/day) }\end{array}$ & $\begin{array}{r}\text { Electrical } \\
+\quad \text { and Gas } \\
(\$ / \text { day })\end{array}$ & $+\begin{array}{c}\text { Chemicals } \\
\text { (\$/day) }\end{array}$ & $=\begin{array}{c}\text { Total } \\
\text { Operating } \\
\text { Costs } \\
(\$ / \text { day })\end{array}$ & $\begin{array}{c}\text { Increase } \\
\text { Beyond } \\
\text { Secondary } \\
(\%)\end{array}$ \\
\hline Secondary & 172.00 & 5.99 & - & 177.99 & - \\
\hline $\begin{array}{l}\text { Tertiary } \\
\text { Clarification }\end{array}$ & 201.00 & 6.78 & 8.92 & 216.70 & 22.0 \\
\hline $\begin{array}{l}\text { Mixed-Media } \\
\text { Filtration }\end{array}$ & 230.00 & 8.32 & 11.15 & 249.47 & 40.0 \\
\hline
\end{tabular}

Kilowatt hours per day were calculated using a power factor of 0.87 . During the 14-day study period, the cost per kilowatt hour at the sewage treatment plant was $\$ .0148$. The digestor sludge was heated by a natural-gas-burning boiler and heat exchanger. Consumption of natural gas by the boiler was not measured directly, but it was estimated at $4,390 \mathrm{ft}^{3}$ per day for a total cost of $\$ 3.29$ per day. That amount accounted for about 40 percent of the total energy cost for the treatment plant. Since boiler operation accounted for a major portion of the energy costs, the cost of digesting sludge was divided proportionately between the three effluents according to the amount of solids removed at each stage (Table 8).

Daily chemical costs were figured on the base prices of alum and Purifloc being $\$ 0.15$ and $\$ 3.15$ per pound, respectively. Alum costs per day were $\$ 8.86$ while Purifloc costs were $\$ 2.29$ per day. Total chemical costs were $\$ 11.15$ per day. On the basis of additional solids being removed, this total, daily cost was proportioned between the tertiary clarified effluent and the filtered effluent costs and was included in the daily operating cost summary (Table 9).

The total, daily, operating expenses were $\$ 249.47$. The unit cost of treatment was $\$ 1.41$ per thousand gallons. This is extremely high compared to treatment costs at larger, conventional, sewage treatment plants. The major factors at this plant were labor costs associated with around-the-clock operator coverage and with relatively small volumes of water $(177,000$ gallons per day). The unit cost of sewage treatment decreases sharply with increasing plant sizes and flows.

\section{Cost-Benefit Analysis}

Increased construction costs of advanced treatment facilities for sanitary sewage at Rocky Flats were small in comparison to increased operating expenses. Figure 4 indicates that initial construction costs for building the chemical mixing facilities and final clarifier, to effect tertiary treatment, were only about 9 percent more than the estimated current replacement costs of the secondary treatment plant. It costs about 22 percent more, however, to operate the tertiary treatment system. The initial construction cost to produce a filtered effluent was $2 \overline{7}$ percent above the current replacement cost of the secondary plant. This 27 percent included the 9 percent additional cost of the tertiary treatment facilities since these facilities are a prerequisite for mixed media filtration. The additional operating expenses associated with the production of a filtered effluent were 40 percent above those associated with the costs required to produce a secondary effluent.

The effectiveness of tertiary treatment and filtration also are summarized in Figure 4. The tertiary treatment removed an additional 49 percent of the total oxygen demand (TOD) present in the secondary 
FIGURE 4. Cost Benefit Analysis of Tertiary Treatment and Mixed Media Filtration

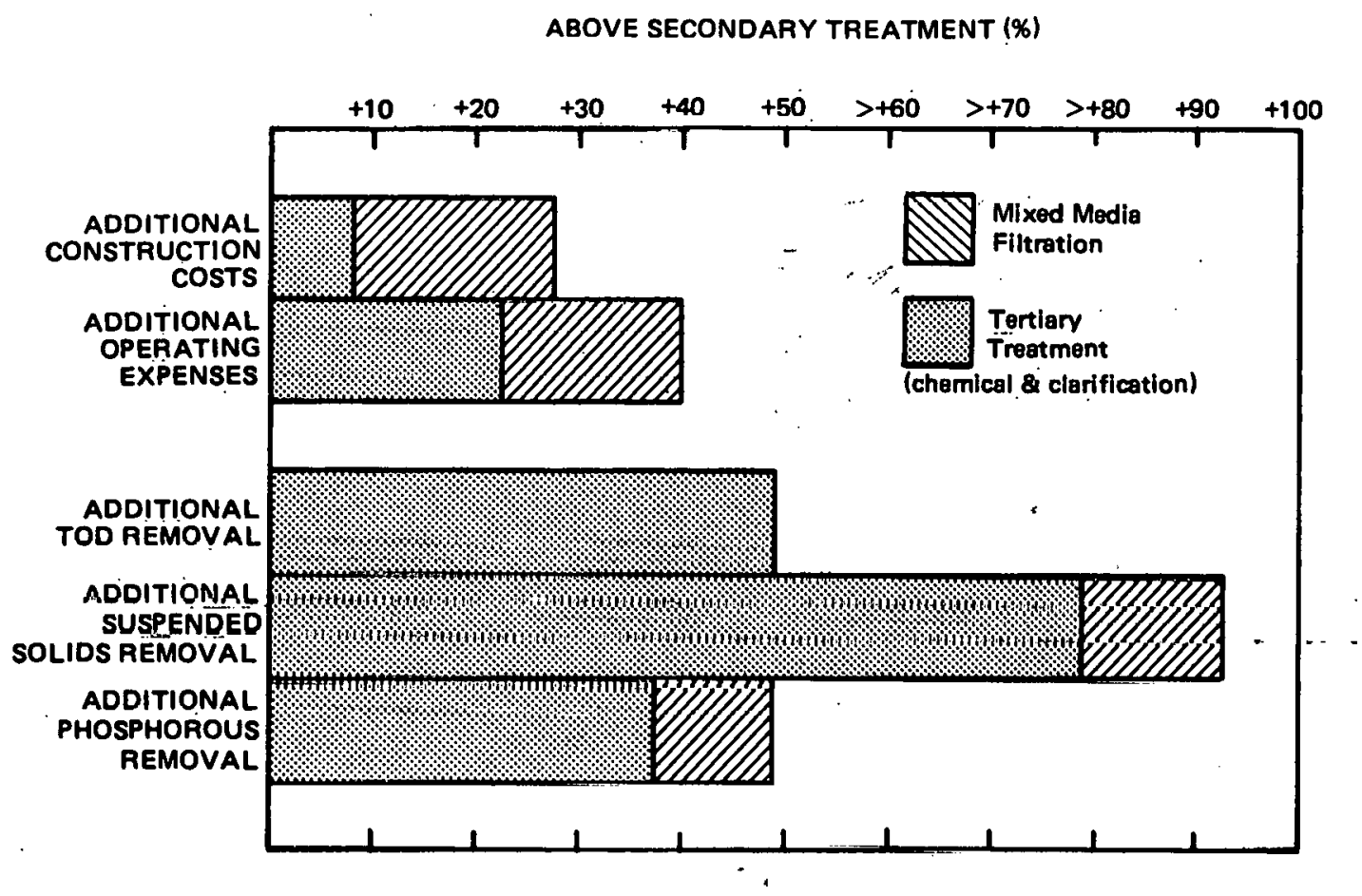

effluent; however, no additional TOD was removed by filtration even though filtration did substantially reduce the amount of suspended solids. The removal of phosphorus was not as good as was expected even though tertiary treatment removed an additional 37 percent over that remaining in the secondary. The filtered phosphorous effluent showed a 48 percent reduction over the secondary. There was no total nitrogen reduction beyond the secondary effluent.

These results indicate that the cost of tertiary treatment, compared to secondary treatment, was more than justitied. Chemical treatment and clarification significantly reduced effluent total oxygen demand, suspended solids, and phosphorous contents. The addition of mixed media filtration was much more costly, however, and provided only small incremental removals of suspended solids and phosphorus. Filtration did not remove any additional total oxygen demand. Filtration costs were justified because the wastewater is being prepared for reverse osmosis and eventual reuse. Reverse osmosis fibers cannot accommodate any appreciable concentration of suspended solids. Since filtration showed only minor reductions in . other waste parameters, it may not be justified at other sites having less restrictive water-quality demands.

\section{SUMMARY}

A secondary treatment plant for sanitary sewage was upgraded by the addition of a chemical precipitation-flocculation system, final clarifier; and mixed-media filters. The influent, secondary effluent, clarified effluent, and filtered effluent were sampled and analyzed for a period of 14 days when water temperatures were between 12 and $14{ }^{\circ} \mathrm{C}$. Construction and operating costs are summarized, and cold weather performance data are reviewed. It was determined that, in comparison to secondary treatment, the additional 9 percent 
construction costs and 22 percent operating costs for tertiary treatment (chemical precipitation, flocculation, and clarification) was more than offset by the improved quality of the liquid effluent. The tertiary effluent showed an additional 49-; 79-, and 37-percent reduction, respectively, for total oxygen demand, suspended solids and phosphorus in the secondary effluent. Mixed-media filtration construction and operating costs were, respectively, 27 and 40 percent more than secondary treatment costs. The filtration reduced concentrations of suspended solids in the secondary effluent by 93 percent, but the solids removed were essentially inert since phosphorus was only slightly reduced and there was no reduction in total nitrogen or total oxygen demand.

\section{REFERENCES}

1. A. W. West. Operational Control Procedures for the Activated Sludge Process. Technical Bulletin EPA-330/9-74-001-6. Part I, Observations; Part II, Control Tests. USEPA
Office of Enforcement and General Counsel. May 1974.

2. A. W. West. Operational Control Procedures for the Activated Sludge Process. Technical Bulletin EPA-330/9-74-001-0. Part III, Calculation Procedures. USEPA Office of Enforcement and General Counsel. December 1973.

3. Environmental Protection Agency Clean Water Methods for Chemical Analysis of Water and Wastes. EPA water Quality, Office of Analytical Quality, Central Lab, 1214 Broadway, Cincinnati, Ohio 45202. 1974.

4. Standard Methods for the Examination of Water Wastewater, 13th Edition. Publication Office: American Public Health, 1740 Broadway, New York, New York 10019. 1974

5. NPDES Permit No. CO-0001333 issued by the U.S. Environmental Protection Agency September 6, 1974. 
RFP-2423

THIS PAGE

\section{WAS INTENTIONALLY \\ LEFT BLANK}

